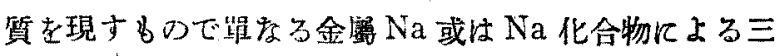

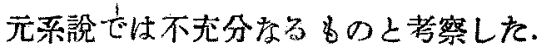

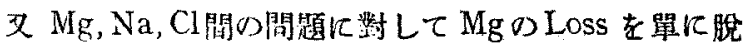

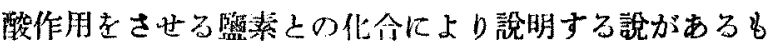

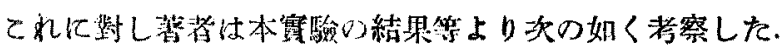

$\mathrm{Mg}$ 添加の際或は $\mathrm{Na}, \mathrm{Cl}$ 等の挿入の際或は添加後の

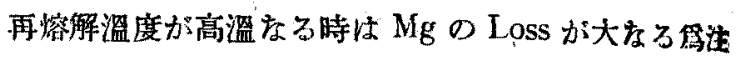
を要す. 然し焀酸劑中に存する $\mathrm{Cl}$ と $\mathrm{Mg}$ との化合K b $\mathrm{MglCl}_{2}$ として Lossすると云ふととは $\mathrm{Na}$ そ蛙 へられない事が偏晶的反應をする $\mathrm{Naが} \mathrm{Cl}$ と作用し い事とは多少異をるるの故りとの汒意が必要であると 察したものである.

\title{
$\mathrm{Al}-\mathrm{Mg}$ 系 合 金の研究 (第 3 報 $)^{*}$ $\mathrm{Al}-\mathrm{Mg}-\mathrm{Mn}$ 合金の機械的性質並に耐触性
}

\section{三島秀 雄**}

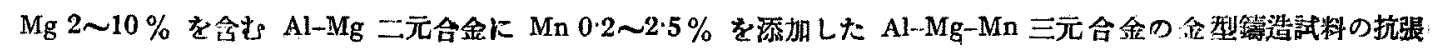

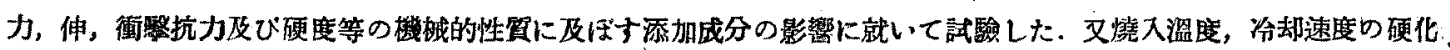

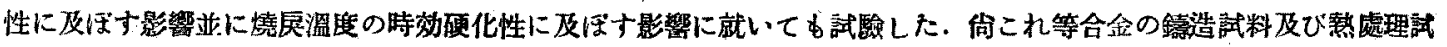

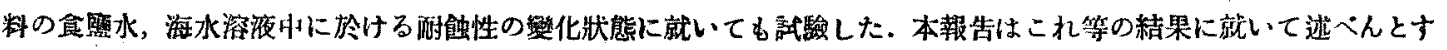
るむのでる。.

(昭和 18 年 12 月 28 日受理)

\section{I. 緹}

著者は襄に第 1 報(1) で $\mathrm{Al}-\mathrm{Mg}$ 二元合金の機械的性質 並飞酎蝕性江就いて速一，更飞 $\mathrm{Mg} 7 \% ， \mathrm{Mn} 0.5 \%$ 程度 を含を筫用ヒドロナリウム押出棒几就いて試驗した結果

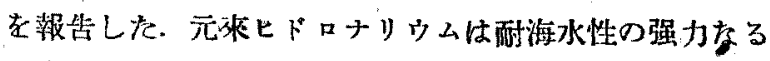
合金にしててれれには必ず少量の Mn 索耐蝕性增加の目 的を以つて源加せられてるる。既に第 1 報でる明らかに せる如く, $\mathrm{Al}-\mathrm{Mg}$ 合金は普通 $\mathrm{Mg}$ 合量が $6 \sim 7 \%$ の のが强度も酎蝕性も優秀なる值を示す故に、ての程度の $\mathrm{Mg}$ 含量のるのが躊造品又は鍛造品として先づ考へられ るが，更に鐶物用としては最近 Mg 10〜12\% 程度のも のも良好存る成績走示すと云はれてるる。

ヒドロナリウムは前述の如く耐海水性の强い合金であ

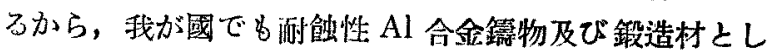

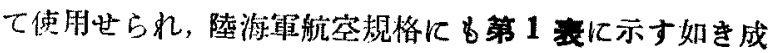
分及び性筫が规定世られてるる。各國に於て筫用世ら れつ!ある $\mathrm{Al}-\mathrm{Mg}-\mathrm{Mn}$ 合金の成分在示世ば第2 表の 如くで，この中 Hydronalium 及び Birmabright は $\mathrm{Mg}$ 含量が比较的多くして Mn 含量が少く，他のるのは $\mathrm{Mg}$ 1〜2\%程度を含む代りにMn $1.25 \sim 2.5 \%$ を含有する 合金で何㣗も酎海水性の强いものである. 斯くの如く耐

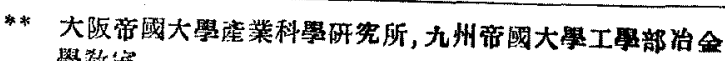
整妓管

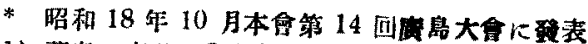

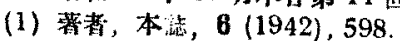

蝕性合金として Mn は缺く可からさるものであるが， Mn 含量と機峨的性筫, 時效硬化性及び耐蝕性との關保

第 1 笠

\begin{tabular}{|c|c|c|c|c|c|c|c|}
\hline \multirow{2}{*}{ 種 } & \multirow{2}{*}{ 類 } & \multicolumn{2}{|c|}{ 化 } & \multicolumn{3}{|c|}{ 分 } & \multirow{2}{*}{ 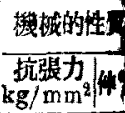 } \\
\hline & & $\mathrm{Mg} \%$ & $\mathrm{Mn} \%$ & $\mathrm{Si} \%$ & $\mathrm{Fe} \%$ & $\mathrm{Al} \%$ & \\
\hline 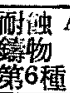 & & $4.0 \sim 7.0$ & $0.1 \sim 0.5$ & $<0.6$ & $<0.6$ & 残部 & $>18$ \\
\hline 耐芧了 & $\begin{array}{c}\text { 合金 } \\
403)\end{array}$ & $6.0 \sim 8.0$ & $0.1 \sim 0.5$ & $<0.5$ & $<0.5$ & ", & $>\mathbf{3 0}$ \\
\hline
\end{tabular}

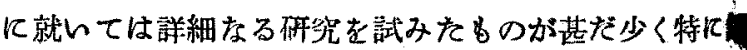
物に於て少然りである. 因つて著者は Mg 2.0 $10.00 \%$

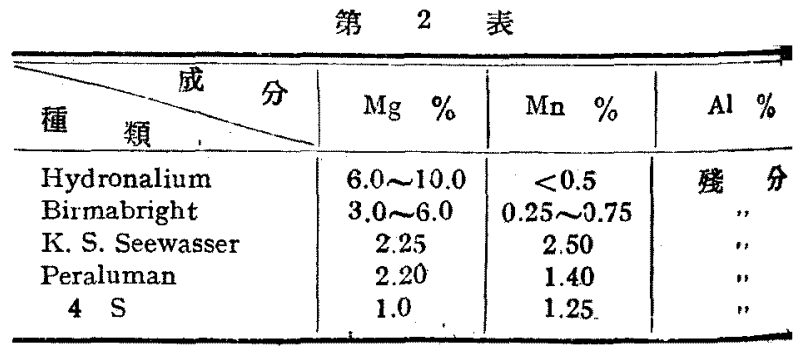

を含む $\mathrm{Al}-\mathrm{Mg}$ 二元合金に $\mathrm{Mn} 0.2 \sim 2.5 \%$ 孝深加山 Al-Mg-Mn 三元合金の鍗造材に就的て研究走企てた である・

\section{II. 徒来の研究}

著者は管て Al-Mg-Mn 三元柔合金の基礎をなす 


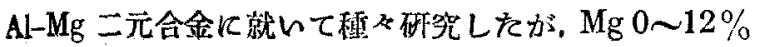
を含む Al-Mg 二元合金の鑄造状態に於りる諸性啠に就 レて研究せる結果に依れば，抗㖘力は $\mathrm{Mg} 6 \%$ 迄は $\mathrm{Mg}$ 含量の增加と共に急激にてれを管加するが，それ以上で 㙁加の割合が少く，伸はてれと反對に Mg 4\% 附近迄 は急激に減少するが，それ以上では減少が少ん，又徆撃 值は $\mathrm{Mg} 2 \%$ 迄は寜る增加するが，それ以上 $\mathrm{Mg}$ を含 しと著しく減少する.向硬度は Mgの含量と共に霄加の

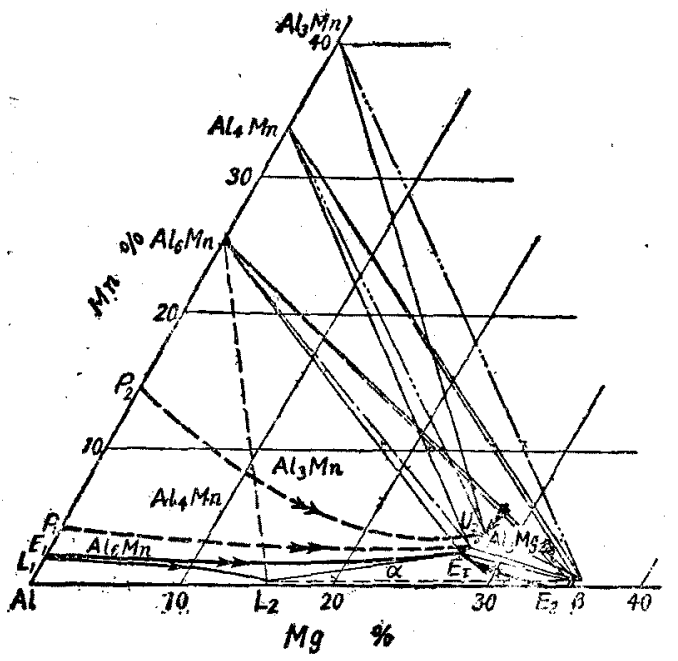

第 1 圖 Al-Mg-Mn 安定系狀態圖

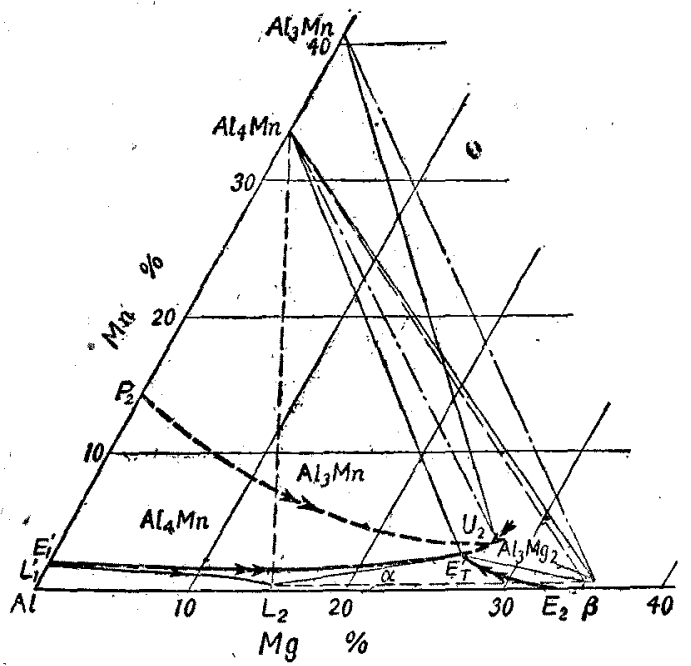

第 2 圆 Al-Mg-Mn 淮安定森狀態圆

傾问を示してみる. 又耐蝕性は $\mathrm{Mg} 2 \%$ 迄以却つて純 $\mathrm{Al}$ の場合よりも劣るが， $\mathrm{Mg}$ 含量をそれ以上に增加すれ 代矢第几酎能性を增加し，Mg6\%附近で最大の耐玲性

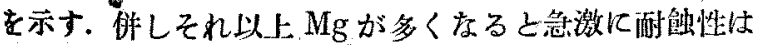

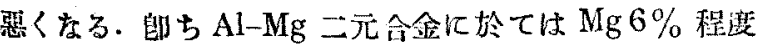
のものが蛰度も耐蝕性も良好である上云へる。

又 $\mathrm{Al}-\mathrm{Mn}$ 合金に於ては抗㖘力は $\mathrm{Mn} \mathrm{1.5 \sim 2.0 \% で}$
最它大となると云はれてるる(2). 份 Bosshard ${ }^{(3)}$ は抗張 力は Mn 1.5\% で鼠高去し，耐蝕性は Mn 1.0\% 以上

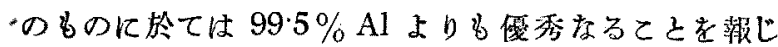
てるる. 然るに Al-Mg-Mn 三元系合金に關方る機械的

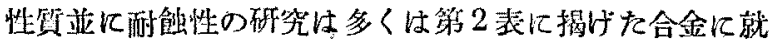
んて極く断片的にその性質を試驗せる程度に止り絓つた ものは全然るい. 特に廣筙圈に涉る $\mathrm{Mg}$ 及び $\mathrm{Mn}$ 相互間 の閐係に於て然りである。因つて本報告では $\mathrm{Al}-\mathrm{Mg}$ 来

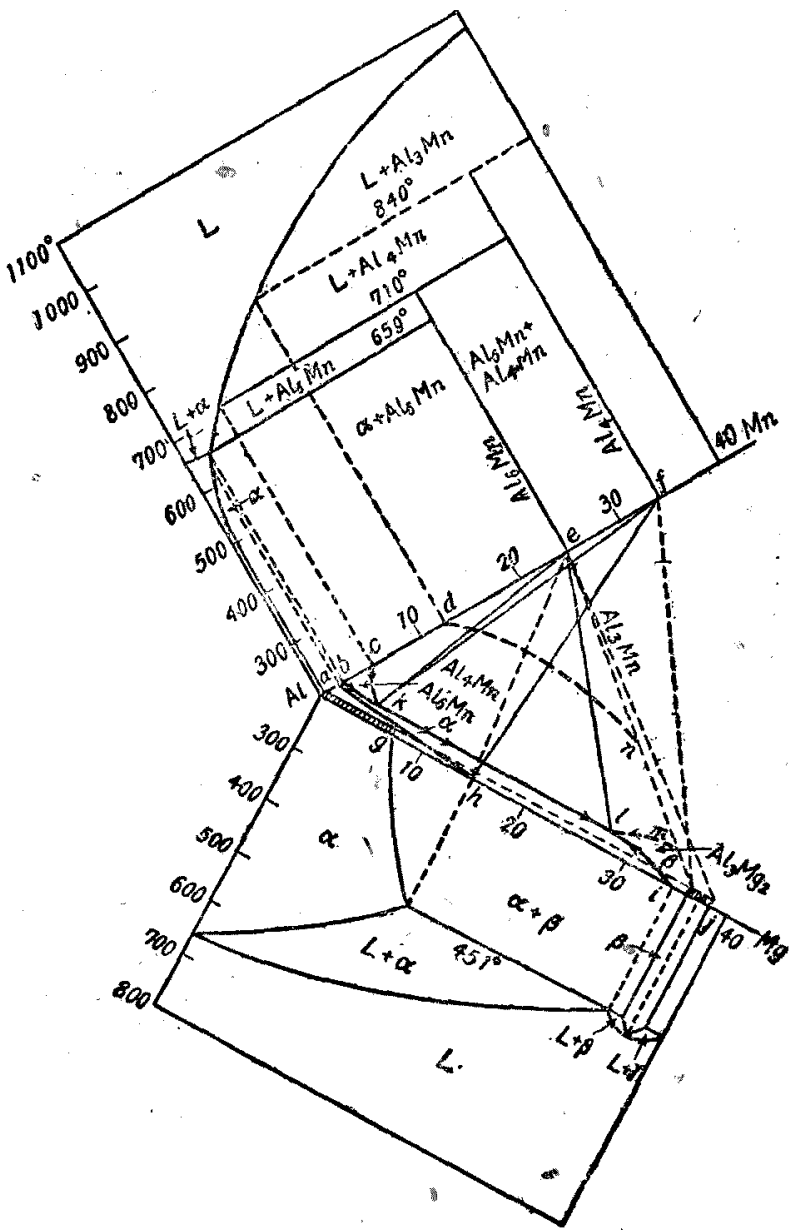

第 3 圆 AI-Mg-Mn 采平衡狀態圆

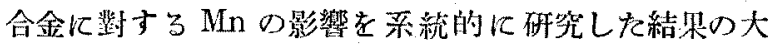
留に就いて逃べんとするものである。

$\mathrm{A} 1-\mathrm{Mg}-\mathrm{Mn}$ 三元系合金の平衡狀態國は Leemann ${ }^{(4)}$ に依り第 1 圆及第 2 圖に示す如を安走系及び华安定 系平衡状熊圆が提示せられて居る。こねと供れば第 1 閣 の安定系狀態圆では $\mathrm{Al}_{6} \mathrm{Mn}$ の初晶面証認めてわるが，

（2）酉村㞣雄，アルミ二ウム及其合全，（1941） 54

(3) M. Bosshard, Light Metals Research, 2 (1932), 9.

(4) W. G. Leemann, Aluminium Archiv, 9 1938), 1 ; 2. Metalłk., 30 (1938), 385. 
第 2 圆の準安定系状態圆では $\mathrm{Al}_{6} \mathrm{Mn}$ の初晶面を生ぜず して $\alpha, \beta, \mathrm{Al}_{4}^{4} \mathrm{Mn}$ の元共晶が现は扎ると云ふ。而し

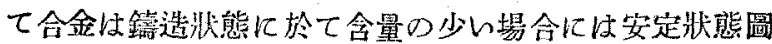
几從つて凝固し $\mathrm{Al}_{6} \mathrm{Mn}$ 老生ずるも， $\mathrm{Mg}$ 含量が高けれ

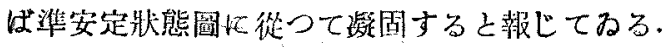

然るに最近森永卢戈氏 ${ }^{(5)}$ は Leemann の狀態圖を第

3 囷の如く改良してるる。圆中 $a b k l i$ 界域は $\alpha, b c k$ 界 域は $\mathrm{Al}_{6} \mathrm{Mn}$ の初晶面， $c d m l k$ 界域は $\mathrm{Al}_{4} \mathrm{Mn}$ の初晶

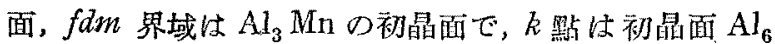
$\mathrm{Mn}, \mathrm{Al}_{4} \mathrm{Mn}$ 及び $\alpha$ の三元包共晶點で, $l$ 點け $\alpha, \beta\left(\mathrm{Al}_{3}\right.$ $\left.\mathrm{Mg}_{2}\right)$ 及び $\mathrm{Al}_{4} \mathrm{Mn}$ の三元共晶點である. この Leemann

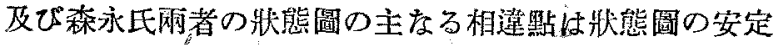
性を撤去して新しく三元包共晶點 $k$ 老設り，初晶面 $\mathrm{Al}_{6}$ $\mathrm{Mn}$ 怙 $b c k$ 界域の及にてれ限定したてとね, $\mathrm{Al}_{3} \mathrm{Mn}$ と $\mathrm{Al}_{4} \mathrm{Mn}$ の初晶面の境界線 $d m$ (Leemann の圖では $\mathrm{P}_{2}$ $\mathrm{U}_{2}$ ) が Leemänn の結果と一致しないてとでする.

著者の研究せる算圍內の合金は $\mathrm{Mg} 10 \%$ 以下，Mn $2.5 \%$ 以下をる故この大部分は $\alpha$ 界域にして一部 分のみが $\alpha+\mathrm{Al}_{6} \mathrm{Mn}$ 或は $\alpha+\mathrm{Al}_{4} \mathrm{Mn}$ 界域に入る譯で ある。

\section{III. 試料の調製及び實驗方法}

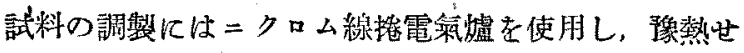

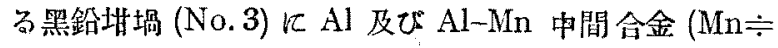

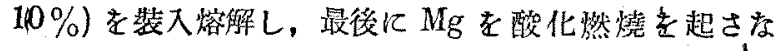

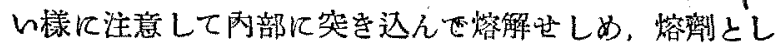

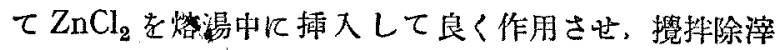
の後徑 13mm の金型儿鍧造した。試料は $\mathrm{Mg} 2 \sim 10 \%$ 含む $\mathrm{Al}-\mathrm{Mg}$ 二元合金江 $\mathrm{Mn} 0.3 \sim 3.0 \%$ を添加し，各
に於けると同样であるから省略する。

\section{IV. 實 驗 䊅 果}

(1) Al-Mg-Mn 合金の機械的性䨘

Al-Mg-Mn 合金金型䥂造試料の機棧的性質は第 4 回

第 3 表” $\mathrm{Al}-\mathrm{Mg}-\mathrm{Mn}$ 䥂造合金試料的成分

\begin{tabular}{|c|c|c|c|c|c|c|c|}
\hline \multirow{2}{*}{ 番 } & \multirow{2}{*}{ 號 } & \multicolumn{2}{|c|}{ 配．合 } & 分 & 分 & \multicolumn{2}{|l|}{ 析 緒 } \\
\hline & & $\mathrm{Mg} \%$ & $\mathrm{Mn} \%$ & Al \% & $\mathrm{Mg} \%$ & Mn $\%$ & Al $\%$ \\
\hline & 1 & $2 \cdot 0$ & 0.3 & 残，部 & $1 \cdot 535$ & 0.243 & 殕 \\
\hline $\mathrm{E}$ & 2 & $"$ & & $"$ & $2 \cdot 210$ & $0 \cdot 417$ & $"$ \\
\hline E & 3 & 30 & 1 & " & 1.887 & 10 & " \\
\hline E & 4 & " & 1.5 & $"$ & 2.146. & $1 \cdot 237$ & $"$ \\
\hline $\mathrm{E}$ & .5 & ", & 20 & " & 1.931 & 1.550 & " \\
\hline$E$ & 6 & $"$ & $3 \cdot 0$ & $"$ & $2 \cdot 000$ & $2 \cdot 180$ & " \\
\hline$F$ & 1 & $4 \cdot 0$ & 0 & 残 部 & 3.745 & $0 \cdot 182$ & 残 摬 \\
\hline$F$ & 2 & $"$ & 0 & " & $3 \cdot 328$ & 332 & " \\
\hline$F$ & 3 & " & 1 . & " & $3 \cdot 874$ & 0.734 & " \\
\hline F & 4 & " & 1.5 & $"$ & $4 \cdot 180$ & 1.092 & $"$ \\
\hline$F$ & 5 & " & $2 \cdot 0$ & ", & 3.997 & 1.430 & " \\
\hline$F$ & 6 & $"$ & $3 \cdot 0$ & $n$ & 3.737 & 1.862 & " \\
\hline & $6 \mathrm{~B}$ & $"$ & $3 \cdot 0$ & ", & $3 \cdot 900$ & $2 \cdot 182$ & " \\
\hline G & 1 & $7 \cdot 0$ & $0 \cdot 3$ & 线 部 & 6.450 & $0 \cdot 177$ & 醅 \\
\hline $\mathrm{G}^{\circ}$ & 2 & " & 0.6 & $"$ & $6 \cdot 197$ & 0.283 & ", \\
\hline G & 3 & " & 1.0 & " & 6.797 & 07 & " \\
\hline $\mathrm{G}$ & 4 & " & 15 & " & $6 \cdot 7$ & 9 & " \\
\hline G & 5 & " & $2 \cdot 0$ & " & 6.724 & 66 & " \\
\hline G & 6, & " & $3 \cdot 0$ & " & $6 \cdot 505$ & $1 \cdot 767$ & " \\
\hline $\mathbf{G}$ & $6 \mathrm{~B}$ & " & $3 \cdot 0$ & $"$ & 6.357 & $2 \cdot 329$ & " \\
\hline $\mathrm{H}$ & 1 & $10 \cdot 0$ & 0.3 & 线 部 & 10 & 6 & 殘 音 \\
\hline $\mathrm{H}$ & 2 & " & 0.6 & " & & & " \\
\hline $\mathrm{H}$ & 3 & " & 1.0 & $n$ & 9.570 & 10 & " \\
\hline $\mathrm{H}$ & 4 & " & 9.5 & " & $9 \cdot 197$ & 1.2 & " \\
\hline $\mathrm{H}$ & 5 & " & $2 \cdot 0$ & " & $9 \cdot 682$ & 1.512 & $"$ \\
\hline$H$ & 6 & $"$ & $3 \cdot 0$ & 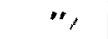 & 10.014 & $1 \cdot 843$ & $"$ \\
\hline $\mathrm{H}$ & $6 \mathrm{~B}$ & & $3 \cdot 0$ & & 25 & $2 \cdot 406$ & " \\
\hline
\end{tabular}

A D 飞示 す如くであ

ろ. この綃 果化传几保 $\mathrm{Mg}$ 含量の 少呞料儿 ありてはMn の添加上共 飞抗镸力t 增加するが $\mathrm{Mg} 4 \%$

籍 4 圆 Al-Mg-Mn 合金鋟造試料の機找的性留
陚料に就いて $300 \mathrm{~g}$ 宛詶㱔した，斯くして合成せる試料 の配合成分及び分析紹果は第 3 表儿示寸如く Mg は大

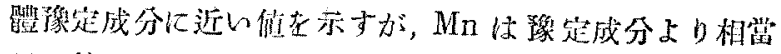

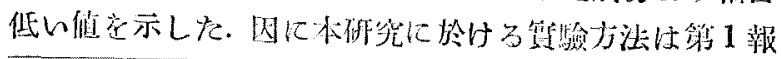

(5) 森永, 本的, 7 (1943), 298.
含むるのにありては Mn 1.0\%, Mg 7\% 及び 10\%を

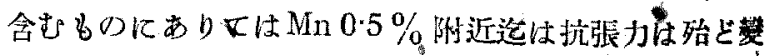
化がをいがそれ以上Mn 学添加する己性質は低下する。

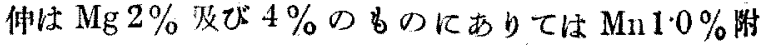
近爮纴 Mnの添加之共に急激にてれ減ずるが，それ以 
上Mgを含むものにありては $\mathrm{Al}-\mathrm{Mg}$ 二元合金自體が既 KMgの添加と共に著しく伸を減少してその值が低い關 係上, てれに Mn 考添加しても伸の減少加前者程著しく

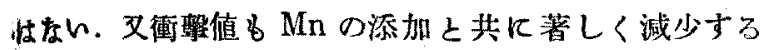
が, $\mathrm{Mg}$ 添加の影響は伸す場合と同樣である.硬度は Mn の添加之共て增加し又 Mgの添加と共に增大寸る.

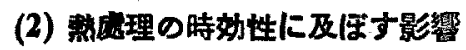

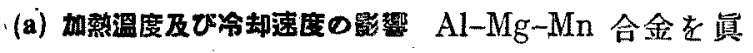
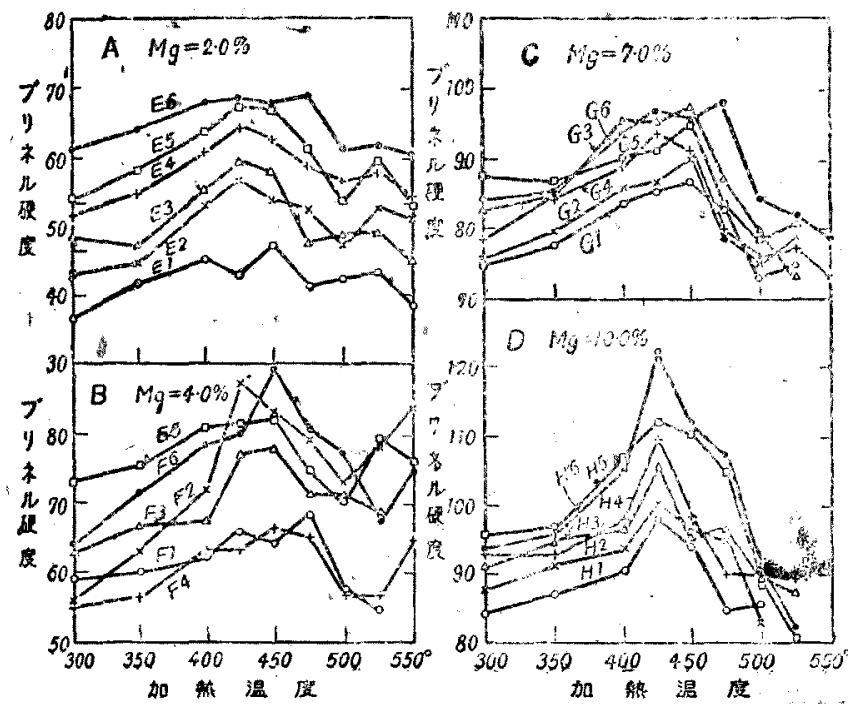

第 5 圆 加熱溫度の硬度に及ぼす影響（水冷の場合）
硬度を增大する倾向を示し，叉Mn 含量索一定と廿る場 合には Mgの添加上共几硬度を增大す万。侗水冷，空渝 网者の硬废老比较すれば水冷せるものと空泠せるもの之 の冷却速度の差異け㱠ど贸められない棈である。

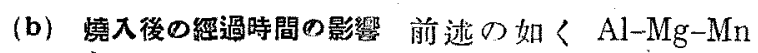
合金は $425 \sim 450^{\circ}$ で漈入せるものが坟大の硬化性考示 す故雨後の燒入處理は全部 $425^{\circ}$ で行ふ。ことにた. $425^{\circ}$ で 1 時間真空加熱し水中急冾後の經過時間の硬化度に及

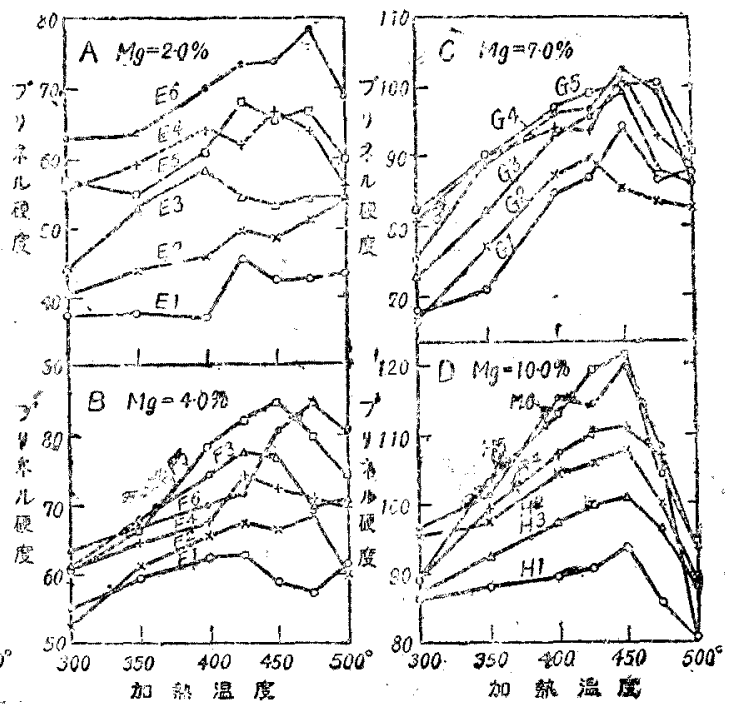

第 6 圆 加熱溫度の硬度に及注寸影響 (空冷の場合)
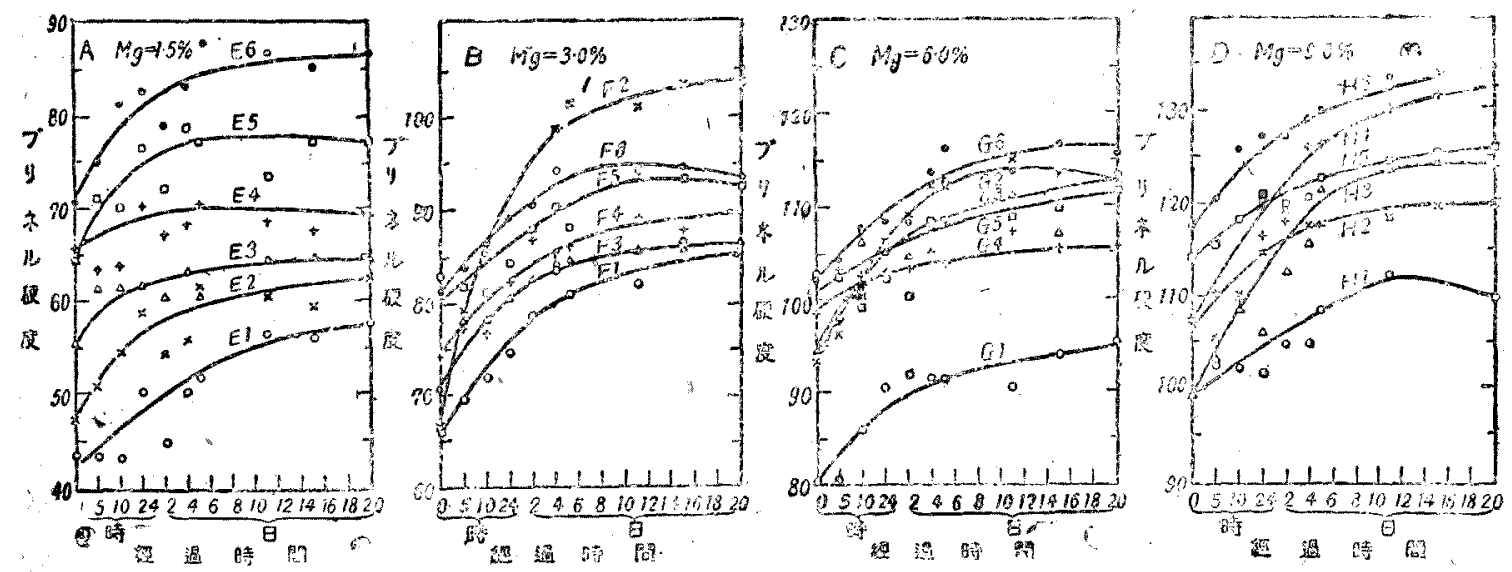

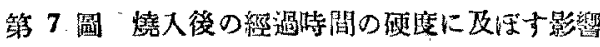

空中にて $300 \sim 550^{\circ}$ K 1 時間加熱後一は水中急泠 L, 他は空中放冷して 24 時間經過後硬度を测定した結果は 第 5 圆及び第 6 圆几示寸如くである。乙れに依れば水 冷，空冾何れの場合に於ても加熱溫菨の上第上共に硬度 を增加し； $425 \sim 450^{\circ}$ で最高の硕度を示し, 尚それ以 上溫度を高的硬度の塯加は認められず却つて低下の

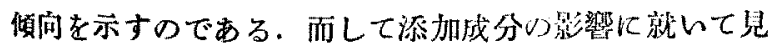
れば $\mathrm{Mg}$ 含量を一定とせる場合には $\mathrm{Mg}$ の湶加と共に

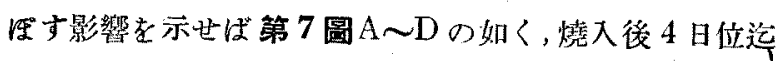
は焙入後の經過時間之共に硬化性を增大するが，それ以 上時日を經過すれば便化の傾向が䌊慢となる.又 $\mathrm{Mn} の$ 添加は空温時效性を妨げるものではなく，Mnの高い試 料でも室溫㭙效性が認められる。而して Mg 含量の 高いもの程㜔大隄後に於ける硬度白高い。

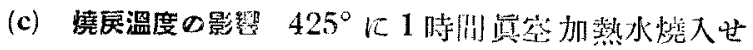

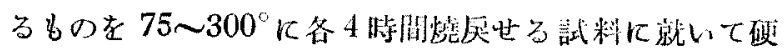


度测定の結思は第 8 圆A D に示す如くである.但し

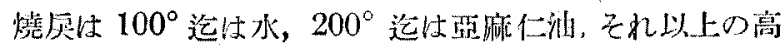

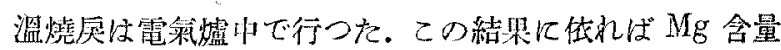
$4 \%$ 迄のbのは接厌に依子硬化性は少いが, $\mathrm{Mg}$ 含量の
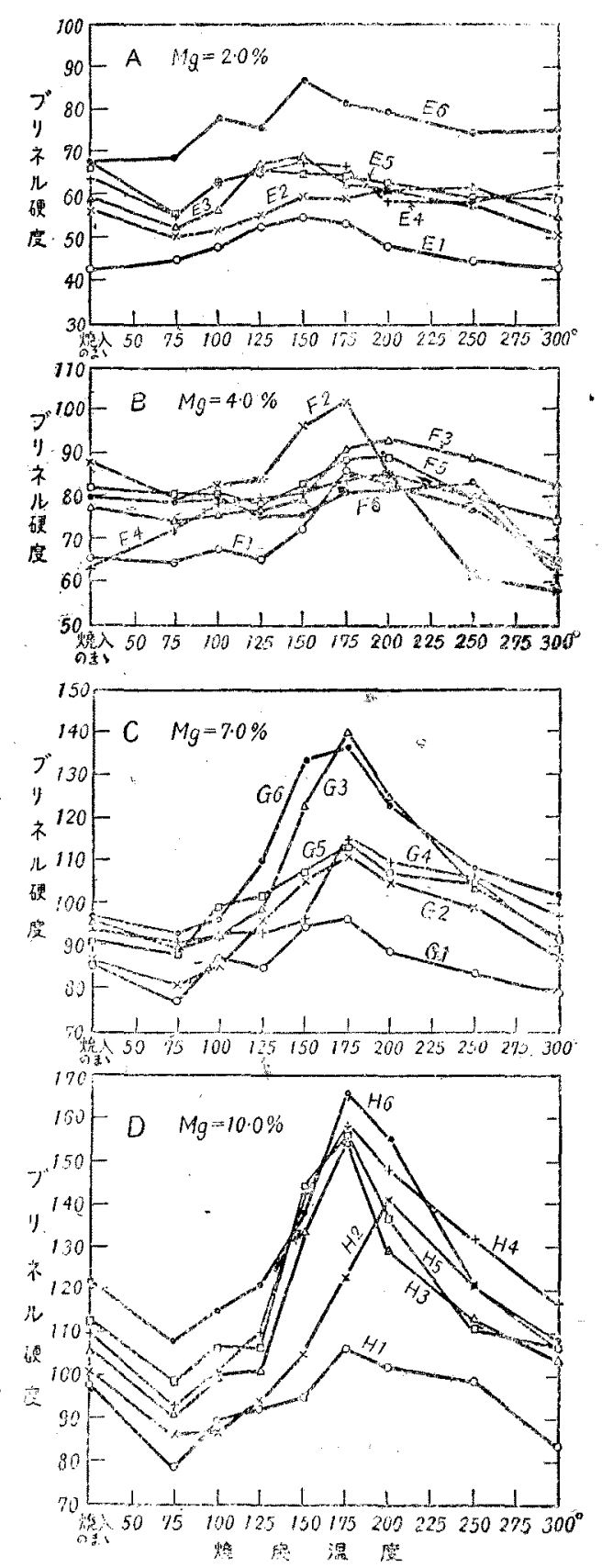

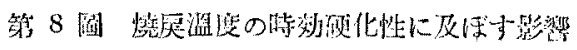

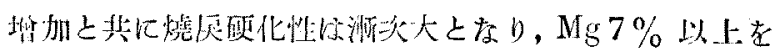

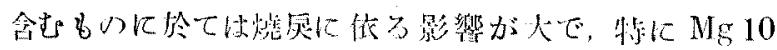

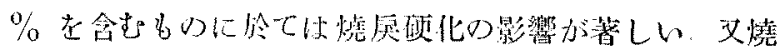

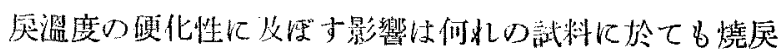

溫度の上早と共に沃邪に硬化性を墦大し $175^{\circ}$ 附近で最 高の硬度を示し，佔それ以上燒㞔溫度を上年せしむれば 却つて硬化度は低下する，又 $\mathrm{Mn}$ 添加硬化度几及汪す 影算に就んて見れば，不規則ではるが概してMn 含量 の岗いるの程硬化性も大なるるの今如くである。

(3) A1-Mg-Mn 合金の耐蝕性

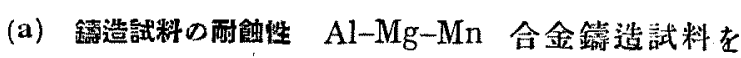
$7 \% \mathrm{NaCl}$ 中に 61 日間浸漬した結果は第 9 图に示す如

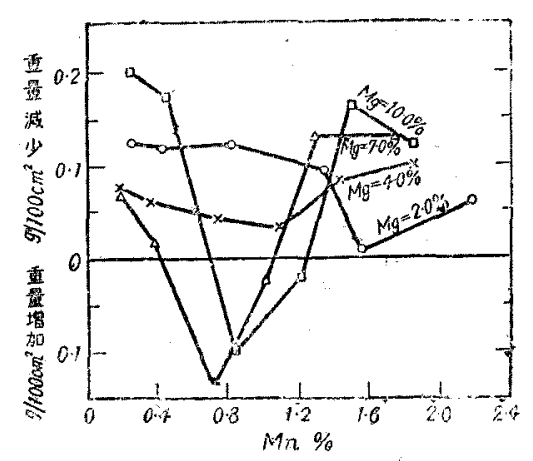

第 9 圖 $\mathrm{Al}-\mathrm{Mg}-\mathrm{Mn}$ 合金䤢造試料の $7 \% \mathrm{NaCl}$ に位る儌触

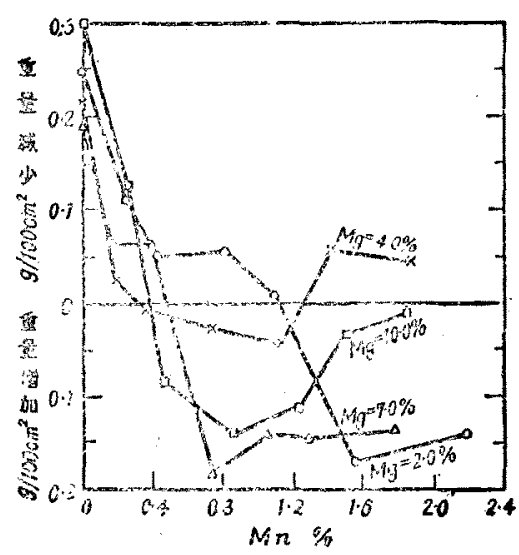

第 10 圖 $\mathrm{Al}-\mathrm{Mg}-\mathrm{Mn}$ 合全鑄造試料の 海水に依る狱飿
<, $M g 2 \%$ 含む它のは Mn $1.5 \%$ 附 近で最良の耐 蝕性を示すが， $\operatorname{Mg~4\% }$ 含 むものは $\mathrm{Mn}$ 約 $1 \cdot 1 \%, \mathrm{Mg} 7$ 及ひ $10 \%$ 娄 含むるのは $\mathrm{Mn}$ 的 $0.8 \%$ で耐蝕性は最 多良好上な る. 又 $\mathrm{Mg}$ 添 加o酎触性江

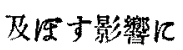
就んて見れば, Mn 1.2\% 以 下儿於ては。 Mg 7 及び 10 \%のものか 酎蝕性㤝優几 てみるが， そ れ以上 Mn 含有する

に於ては. $\mathrm{Mg}$ 含量 2 及び $4 \%$ \%のが耐触性は優れて

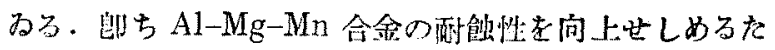
めには, Mg含量の低んもの程多量つ Mn老必要とするわ けである。省䇾造試料を人工的海水中に同じく61 日間 浸清した結果休第 10 圆に示す如くである. この場合に

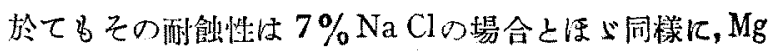
$2 \%$ のものは Mn $1.5 \%$ で最良の耐蝕性を示すが，他の ものは Mn 0.8〜1.2\%で最是となる。而して Mg 添加

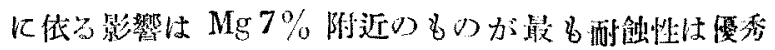

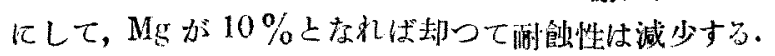
これは前逃の如く $\mathrm{Al}-\mathrm{Mg}$ 二元合金自體が $\mathrm{Mg} 6 \%$ で最 
良の觓蛤性を示すためであららと考入られる。

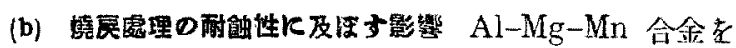

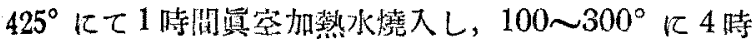
閒燒危した陚料を人工的游水中に60日間浸清した絬果

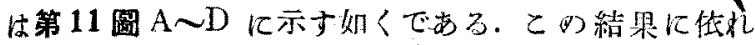

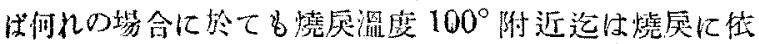

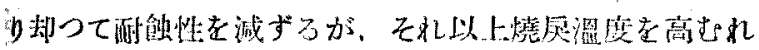

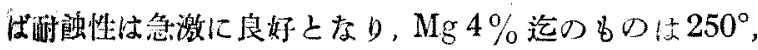

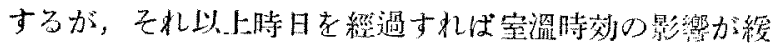

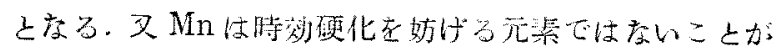
明放后つた。

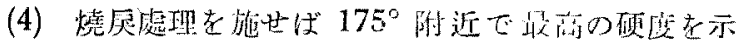
す，而してその硬化㡾は $\mathrm{Mn}$ ○なる程又 $\mathrm{Mg}$ 含最り 大视程大である。

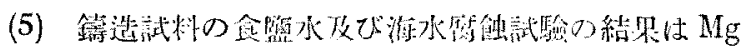
含量 $2 \%$ ののは $\mathrm{Mn} 1.5 \%, \mathrm{Mg} 4 \%$ のものは $\mathrm{Mn}$

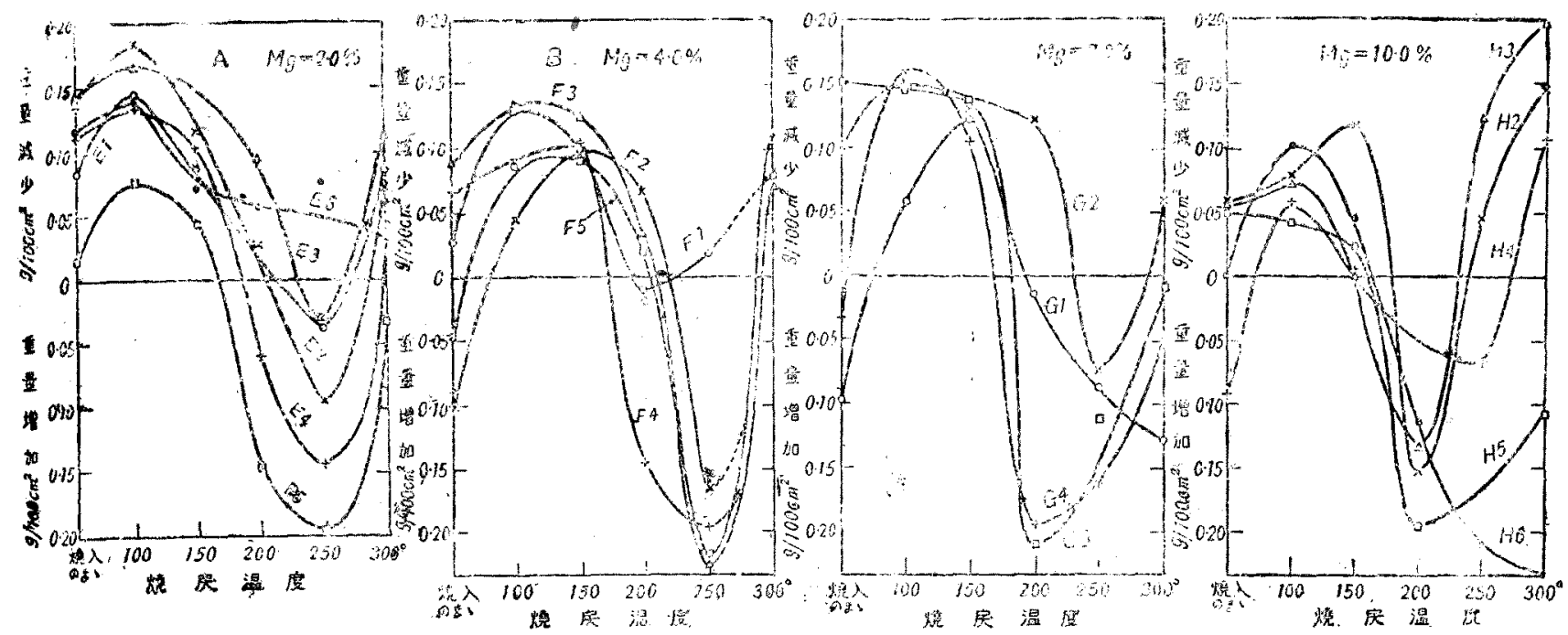

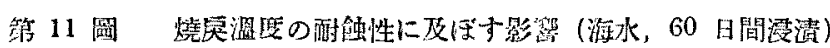

$\mathrm{Mg} 7$ 及び $10 \%$ のbのは $200^{\circ}$ 时近で最皇の耐领性を

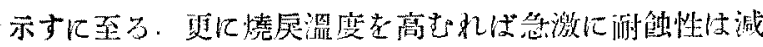
少する，阙しこの原因に就いては米だ結論在得る迄に㤌

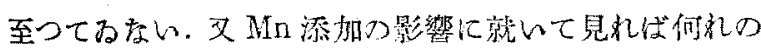

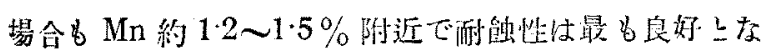
ろもの\如くである。

\section{V. 總括}

以上の絬果を要的すれば大體次の如くである。

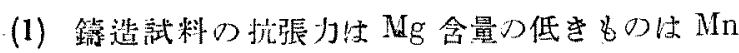
の添加已垬に增加するが， Mg 4\%のbのちMn 1.0\%， Mg 7 及七゙ 10\%のものは Mn 0.5\% 附近上り芜張力老

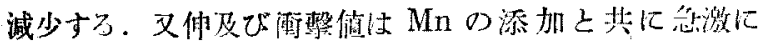
減少し，硬度は Mg 及びMnの湑加上共に大となる。

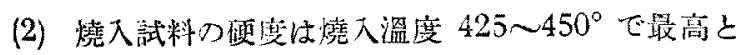

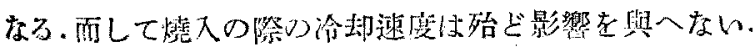

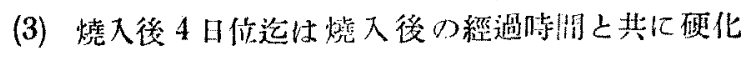

1.1\%, Mg 7 及び $10 \%$ ののはMn 0.8\%で最良の耐 蝕性を示寸。即ち $\mathrm{Mg}$ 含量の少い为の程多量の Mn 添加しなければ耐领性は改㲊せられない。

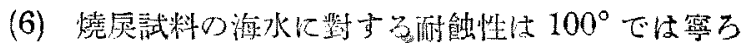

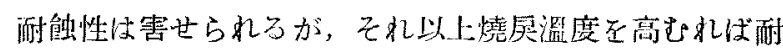

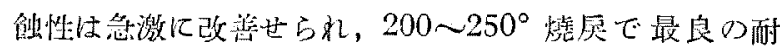
触性老示すに至る。

以上の結果を涌㯺す机代 $\mathrm{Mg}$ 含量の少いものは $\mathrm{Mn}$ の高い所まで機晠的性質の惡化が少く，特に耐玲性の照 から云八ば 1.5\%估迄のMnを渼加する必要がある。 然るに㙜 $\mathrm{Mg}$ 含量のbのにありては $\mathrm{Mn}$ 含皇が $0.5 \%$

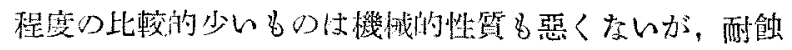

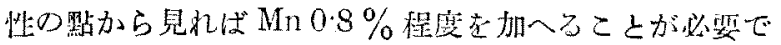
ある視に䍐仿风る。

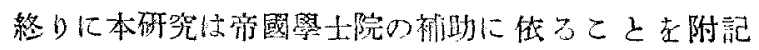

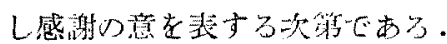

